\title{
Prader-Willi Syndrome and Schaaf-Yang Syndrome: Neurodevelopmental Diseases Intersecting at the MAGEL2 Gene
}

\author{
Michael D. Fountain ${ }^{1,2}$ and Christian P. Schaaf ${ }^{1,2, *}$ \\ Received: 2 December 2015; Accepted: 11 January 2016; Published: 13 January 2016 \\ Academic Editor: Danny Camfferman \\ 1 Interdepartmental Program in Translational Biology and Molecular Medicine, Department of Molecular and \\ Human Genetics, Baylor College of Medicine, Houston, TX 77030, USA; mfountai@bcm.edu \\ 2 Jan and Dan Duncan Neurological Research Institute, Texas Children's Hospital, Houston, TX 77030, USA \\ * Correspondence: schaaf@bcm.edu; Tel.: +1-832-824-8787
}

\begin{abstract}
Prader-Willi syndrome (PWS) is a neurodevelopmental disorder characterized by neonatal hypotonia, developmental delay/intellectual disability, and characteristic feeding behaviors with failure to thrive during infancy; followed by hyperphagia and excessive weight gain later in childhood. Individuals with PWS also manifest complex behavioral phenotypes. Approximately 25\% meet criteria for autism spectrum disorder (ASD). PWS is caused by the absence of paternally expressed, maternally silenced genes at chromosome 15q11-q13. MAGEL2 is one of five protein-coding genes in the PWS-critical domain. Truncating point mutations of the paternal allele of MAGEL2 cause Schaaf-Yang syndrome, which has significant phenotypic overlap with PWS, but is also clinically distinct; based on the presence of joint contractures, and a particularly high prevalence of autism spectrum disorder (up to $75 \%$ of affected individuals). The clinical and molecular overlap between PWS and Schaaf-Yang syndrome, but also their distinguishing features provide insight into the pathogenetic mechanisms underlying both disorders.
\end{abstract}

Keywords: Prader-Willi syndrome; Schaaf-Yang syndrome; MAGEL2; USP7; neurodevelopmental disorders

\section{Introduction}

Prader-Willi syndrome (PWS) is a complex genetic disorder caused from alterations of the paternally expressed genes on chromosome 15q11-q13 [1]. In the early years of life, individuals with PWS manifest severe hypotonia, feeding difficulties, failure to thrive, and developmental delays [2]. Hypogonadotropic hypogonadism is present, most readily appreciated in boys due to undescended testicles and a hypoplastic phallus. Following the marked feeding difficulties during infancy, children with PWS will then go on to develop hyperphagia, leading to morbid obesity unless diet is restricted [1,2]. As the children get older, a typical cognitive and behavioral profile becomes evident. Most are affected with intellectual disability. Their behavior is comprised of stubbornness, temper tantrums, manipulative and compulsive behaviors [3,4]. Strabismus, scoliosis, and sleep disturbances are also noted. Characteristic facial dysmorphisms include a narrowed bifrontal diameter, almond-shaped palpebral fissures, a narrow nasal bridge, and down-turned corners of the mouth, which may be apparent at birth and/or can manifest with time [1,2].

The PWS critical region lies within a $6 \mathrm{Mb}$ genomic locus on the long arm of chromosome 15. The two primary molecular causes of PWS include deletion of paternal 15q11-q13, which is present in $65 \%-75 \%$ of individuals with PWS, and maternal uniparental disomy, present $20 \%-30 \%$ of cases. Defects of the imprinting center are observed in $1 \%-3 \%$ of cases [3,5-7]. The maternally imprinted, 
paternally expressed genes included in the PWS-critical region are MKRN3, MAGEL2, NDN, NPAP1, SNURF-SNRPN, and a family of six small nucleolar RNA (snoRNA) genes [1,7].

While the vast majority of individuals with PWS have loss of expression of all of these genes, a small number of cases have been reported that may help elucidate which genes account for some of the phenotypes characteristic of PWS. A lot of interest has focused on the region containing the SNORD116 snoRNA cluster, as its loss appears to account for several key phenotypes observed in PWS. An individual with microdeletion of the SNORD116 cluster was reported to manifest neonatal hypotonia, feeding difficulties and failure to thrive, then hyperphagia leading to morbid obesity, hypogonadism, developmental delay, and some PWS facial features [8]. In addition, this individual met criteria for autism spectrum disorder (ASD), based on the Autism Diagnostic Observation Schedule (ADOS) and Autism Diagnostic Interview-Revised (ADI-R). Subsequently, two additional cases were reported with overlapping microdeletions including SNORD116, and both manifested similar clinical features, including hyperphagia and obesity $[9,10]$.

\section{The MAGEL2 Gene in Prader-Willi Syndrome and Schaaf-Yang Syndrome}

More recently, a series of individuals with point mutations in a protein-coding gene of the PWS domain was reported. Whole genome and whole exome sequencing identified four individuals with truncating pathogenic variants in MAGEL2. These initial individuals manifested a phenotypic spectrum of neonatal hypotonia, feeding difficulties, weight gain, developmental delay/intellectual disability, and hypogonadism [11]. As neonates, all were suspected to have PWS, but standard molecular diagnostic testing, which is based on abnormal methylation patterns of genomic DNA at 15q11-q13, was negative. Two of the four individuals manifested contractures of the finger joints. All four were clinically assessed and diagnosed with ASD based on DSM-IV criteria. Interestingly, these individuals tended to lack the extreme hyperphagia, and subsequently did not develop the morbid obesity that is typically seen in untreated PWS as evidenced by the calculated body mass indices (Table 1). This suggested a disease entity similar to PWS, yet distinct, and was subsequently named Schaaf-Yang syndrome (OMIM 615547).

Table 1. Height, weight, and BMI of reported individuals with truncating point mutations or whole gene deletions of MAGEL2.

\begin{tabular}{|c|c|c|c|c|c|c|c|c|c|}
\hline Patient & Mutation Type & Age & Sex & Height & $\begin{array}{l}\text { Height } \\
\text { Z-Score }\end{array}$ & Weight & $\begin{array}{l}\text { Weight } \\
\text { Z-Score }\end{array}$ & BMI & $\begin{array}{c}\text { BMI } \\
\text { Z-Score }\end{array}$ \\
\hline $\begin{array}{l}\text { Schaaf et al. } \\
\text { subject } 1\end{array}$ & $\begin{array}{c}\text { Truncating } \\
\text { point mutation }\end{array}$ & 13 yo & $\mathrm{M}$ & $156 \mathrm{~cm}$ & -0.03 & $54.2 \mathrm{~kg}$ & 0.82 & 22.3 & 1.13 \\
\hline $\begin{array}{l}\text { Schaaf et al. } \\
\text { subject } 2\end{array}$ & $\begin{array}{c}\text { Truncating } \\
\text { point mutation }\end{array}$ & $\begin{array}{l}7 \mathrm{yr} \\
6 \mathrm{mo}\end{array}$ & $\mathrm{M}$ & $134 \mathrm{~cm}$ & 1.65 & $68.3 \mathrm{~kg}$ & 3 & 38 & 2.99 \\
\hline $\begin{array}{l}\text { Schaaf et al. } \\
\text { subject } 3\end{array}$ & $\begin{array}{c}\text { Truncating } \\
\text { point mutation }\end{array}$ & 5 уо & $\mathrm{M}$ & $105 \mathrm{~cm}$ & -0.91 & $19.6 \mathrm{~kg}$ & 0.42 & 17.8 & 1.56 \\
\hline $\begin{array}{l}\text { Schaaf et al. } \\
\text { subject } 4\end{array}$ & $\begin{array}{c}\text { Truncating } \\
\text { point mutation }\end{array}$ & $\begin{array}{l}19 \text { yo } \\
5 \text { mo }\end{array}$ & $\mathrm{M}$ & $148 \mathrm{~cm}$ & -3 & $47.9 \mathrm{~kg}$ & -2.84 & 21.9 & -0.29 \\
\hline $\begin{array}{l}\text { Soden et al. } \\
\text { subject } 382\end{array}$ & $\begin{array}{c}\text { Truncating } \\
\text { point mutation }\end{array}$ & 11 yo & $\mathrm{F}$ & $140 \mathrm{~cm}$ & -0.55 & $60.8 \mathrm{~kg}$ & 2.02 & 31 & 2.35 \\
\hline $\begin{array}{l}\text { Soden et al. } \\
\text { subject } 383\end{array}$ & $\begin{array}{c}\text { Truncating } \\
\text { point mutation }\end{array}$ & 8 уо & $\mathrm{F}$ & $107 \mathrm{~cm}$ & -3 & $16.7 \mathrm{~kg}$ & -3 & 14.6 & -0.77 \\
\hline $\begin{array}{l}\text { Kanber et al. } \\
\text { patient } 1\end{array}$ & Gene deletion & 7 уо & $\mathrm{F}$ & $140 \mathrm{~cm}$ & 3 & $41 \mathrm{~kg}$ & 2.6 & 20.9 & 1.92 \\
\hline $\begin{array}{l}\text { Buiting et al. } \\
\text { patient } 1\end{array}$ & Gene deletion & 3 уо & M & $102.5 \mathrm{~cm}$ & 1.86 & $17.3 \mathrm{~kg}$ & 1.59 & 16.5 & 0.37 \\
\hline
\end{tabular}

In contrast to those point mutation cases, individuals with deletions including MAGEL2, but not the SNORD116 cluster, were reported to have much milder phenotypes overall $[12,13]$. Indeed, 
while these individuals displayed some motor and developmental delays, with one manifesting mild feeding difficulties, the reporting physicians emphasized that their phenotypic severity was much milder than what is typically seen or reported in PWS and Schaaf-Yang syndrome. Moreover, based on a detailed clinical assessment, no joint contractures, signs of autism, or hyperphagia were reported in either MAGEL2 whole gene deletion case. The authors of the respective publications had taken this as evidence that loss of MAGEL2 might not contribute to the pathogenesis of PWS. The idea that a deletion of the entire gene could have a milder effect than a truncating mutation seems paradoxical, and is worth further deliberation. The deletion of the complete paternal copy of the gene and promoter could lead to leaky expression of the maternal copy of the MAGEL2 gene, as suggested based on studies of mice lacking the paternal MAGEL2 copy [14]. On the other hand, truncating mutations of the single-exon gene MAGEL2 would not be expected to cause nonsense-medicated decay of mRNA, but to lead to a truncated protein product, which may have neomorphic effects.

\subsection{Schaaf-Yang Syndrome vs. Prader-Willi Syndrome}

Since the initial identification of truncating point mutations in MAGEL2 leading to Schaaf-Yang syndrome, two more studies have identified additional individuals with MAGEL2 point mutations. Soden et al. [15] reported two sisters manifesting decreased fetal movement, neonatal hypotonia, feeding difficulties, developmental delay, and intellectual disability. Both were diagnosed with ASD, and both had contractures of the hands. Hyperphagia, obesity, or PWS facial characteristics were not reported. Mejlachowicz et al. [16] identified three fetal siblings manifesting lethal arthrogryposis multiplex congenita (i.e., contractures and decreased fetal movement). Whole exome sequencing revealed the presence of a truncating pathogenic variant in MAGEL2, subsequently proven to be present on the paternal allele. One additional, unrelated individual with a de novo truncating pathogenic variant in MAGEL2 was identified by Sanger sequencing of MAGEL2 in a cohort of individuals with arthrogryposis and/or decreased fetal mobility. This individual manifested microretrognathia, a short neck, and small joint contractures. Moreover, this individual manifested severe hypotonia and died on postnatal day 2 from respiratory distress. Due to the age of this individual, assessment for ASD could not be performed. Pathological examination of other organs and systems were reported as normal.

Taken together, the published data suggest a role for MAGEL2 in PWS and beyond. Both PWS and MAGEL2-associated Schaaf-Yang syndrome manifest clinical phenotypes that overlap, and Schaaf-Yang syndrome should be considered an important differential diagnosis of PWS, in particular in the newborn period. Common overlapping phenotypes include neonatal hypotonia, feeding difficulties, hypogonadism, developmental delay and intellectual disability (Figure 1). On the other hand, some clinical features highlight a clinical profile that is unique and distinct from one another. Contractures, which are typically not present in PWS, are seen in a majority of individuals with truncating MAGEL2 point mutations. Similarly, the prevalence of ASD was recently reported as $27 \%$ among individuals with PWS [6]. In contrast, the six individuals with truncating mutations of MAGEL2, who were old enough to be assessed, were all clinically diagnosed with ASD based on DSM-IV criteria. As well, hyperphagia and obesity, which are considered hallmark features of PWS, typically seen in nutritional phases 2 and 3 [1], were prevalent in no more than $50 \%$ of those individuals with Schaaf-Yang syndrome old enough to be assessed (Table 1).

\subsection{Animal Models of Magel2 Loss-of-Function}

Magel 2 loss of function has been studied in animal models (Table 2). Mice with deletion of most of the Magel2 gene and its promoter showed a reduction in hypothalamic oxytocin, and a neonatal mortality of $50 \%$, due to suckling defects. Surviving male mice of that strain were shown to manifest deficits in appreciation of social novelty, novel object exploration, and spatial learning and memory [17]. Importantly, both the neonatal lethality, and the social and learning deficits seen in the adult mice could be rescued by early postnatal oxytocin injections [18]. 


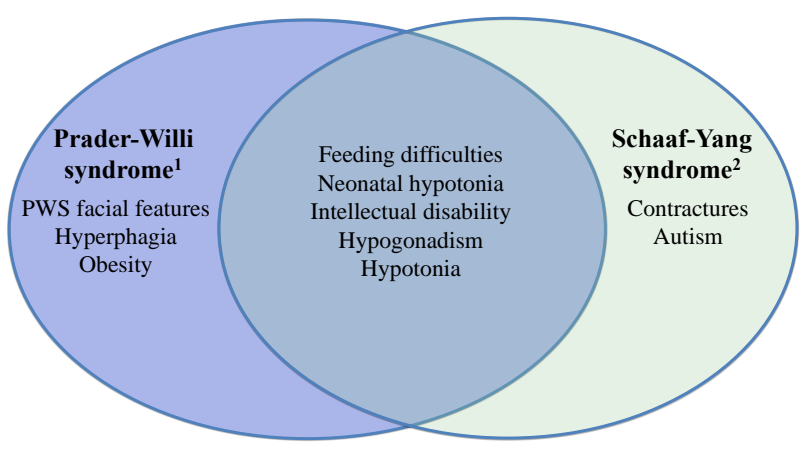

Figure 1. Prader-Willi syndrome and Schaaf-Yang syndrome share common overlapping symptoms, yet have important distinct features. While none of the symptoms listed in this figure may be exclusive to any one condition, the figure attempts to highlight those features that have particularly high prevalence in the respective disorders. Only phenotypes of $>50 \%$ prevalence for the respective disorder are listed. 1 , defined by gene deletions in the $15 \mathrm{q} 11-\mathrm{q} 13$ chromosomal region; ${ }^{2}$, defined by truncating point mutations of the MAGEL2 gene.

Table 2. Comparison of reported phenotypic manifestation of Magel2-null mouse models.

\begin{tabular}{cc}
\hline Wevrick et al. [19-22] & Muscatelli et al. $[\mathbf{1 7 , 1 8 ]}$ \\
\hline Postnatal lethality (10\%) & Neonatal lethality $(50 \%)$ \\
Decreased pre-wean weight gain & Decreased oxytocin quantity \\
Increased post-wean adiposity & Decreased suckling activity \\
Decreased lean mass & Decreased sociability (male mice) \\
Decreased locomotor activity & Decreased learning and memory (male mice) \\
Altered appreciation of novelty & \\
Circadian dysfunction & \\
Progressive infertility & \\
Altered olfaction $(>24$ weeks of age) & \\
\hline
\end{tabular}

Major phenotypes reported by each group of researchers.

A second Magel2 loss-of-function mouse model was created by replacing the Magel2 coding sequence with a $L a c Z$ reporter, and leaving the original promoter intact. These mice displayed alterations in fat and muscle deposition, neurotransmitter signaling, brain volume, reproduction, and behavior in novel environments [19-22]. The two described mouse models show a spectrum of manifested phenotypes, but should not be considered definitive or exclusive to either mouse model. Indeed, it may be that a complete phenotypic profile is yet to be reported. Marked phenotypic differences exist between the two mouse models, most dramatically the difference in survival, with a high percentage of neonatal lethality in one model, which is not seen in the other. While increased body adiposity was reported in one, none of the two models recapitulated the hyperphagia and morbid obesity typically seen in human patients with PWS. The low prevalence of the respective phenotypes in human patients with truncating MAGEL2 mutations may suggest that these phenotypes are, indeed, not attributable to alterations of the MAGEL2 gene and the respective protein.

\subsection{USP7 Haploinsufficiency and Its Related Clinical Phenotypes}

The concept of a molecular and clinical spectrum of disorders is further highlighted by the recent discovery of individuals with loss-of-function mutations in a MAGEL2-interacting protein. Seven individuals were identified to harbor de novo, heterozygous deletions/mutations of the gene encoding for ubiquitin-specific protease 7 (USP7). USP7 was shown to interact with MAGEL2 and TRIM27. The three proteins functionally depend on one another, such that alterations in any of these components lead to alterations in endosomal actin assembly, protein recycling, and a subsequent disruption of cellular homeostasis [23]. The seven individuals with USP7 haploinsufficiency manifested hypotonia, hypogonadism, and developmental delay/intellectual disability, similar to both PWS and 
Schaaf-Yang syndrome. A high prevalence of ASD, similar to that seen in Schaaf-Yang syndrome, was noted in these individuals. In addition, five out of seven individuals with USP7 mutation had seizures, indicating a higher prevalence than in PWS (10\%-20\%) [1] or Schaaf-Yang syndrome (only one described case) [11]. It is important to consider the possibility of an ascertainment bias, such that first reports of new gene-disease associations appear to reflect the more severe end of the actual patient population. However, the phenotypic overlap and differences can be appreciated between the three conditions (Figure 2), and in combination with a detailed molecular understanding of MAGEL2 function, shared pathomechanisms are suggested. At the same time, these recent discoveries suggest that genes encoding for other proteins partaking in WASH ubiquitination and endosomal actin assembly are candidate genes for related neurodevelopmental disorders.

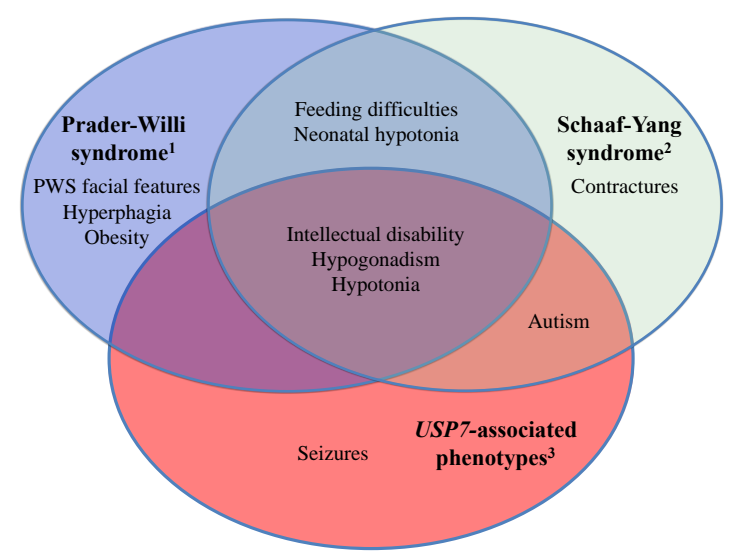

Figure 2. Prader-Willi syndrome, Schaaf-Yang syndrome, and USP7-associated disorder represent a spectrum of neurodevelopmental disorders. Shared and distinct clinical features are illustrated. While none of the symptoms listed may be exclusive to any one condition, the figure attempts to highlight those features that have a high ( $>50 \%$ ) prevalence in the respective disorders. ${ }^{1}$, disorder defined by gene deletions in the 15q11-q13 chromosomal region; ${ }^{2}$, disorder defined by truncating point mutations of the MAGEL2 gene; ${ }^{3}$, disorder defined by a deletion or truncating point mutation of the USP7 gene.

\section{Conclusions}

As technology progresses and more affected individuals are being identified, the clinical and molecular signatures of the various disorders will become increasingly clear. A greater awareness of these disorders will hopefully lead to increased advocacy, research interest, and ultimately better quality of life for the affected individuals.

Acknowledgments: The authors' work was supported by the Joan and Stanford Alexander Family and the Foundation for Prader-Willi Research.

Conflicts of Interest: The authors declare no conflict of interest.

\section{References}

1. Cassidy, S.B.; Schwartz, S.; Miller, J.L.; Driscoll, D.J. Prader-Willi syndrome. Genet. Med. 2012, 14, 10-26. [CrossRef] [PubMed]

2. Holm, V.A.; Cassidy, S.B.; Butler, M.G.; Hanchett, J.M.; Greenswag, L.R.; Whitman, B.Y.; Greenberg, F. Prader-Willi syndrome: Consensus diagnostic criteria. Pediatrics 1993, 91, 398-402. [PubMed]

3. Dykens, E.M.; Lee, E.; Roof, E. Prader-Willi syndrome and autism spectrum disorders: An evolving story. J. Neurodev. Disord. 2011, 3, 225-237. [CrossRef] [PubMed]

4. Rice, L.J.; Einfeld, S.L. Cognitive and behavioural aspects of Prader-Willi syndrome. Curr. Opin. Psychiatry 2015, 28, 102-106. [CrossRef] [PubMed]

5. Dykens, E.M.; Roof, E. Behavior in Prader-Willi syndrome: Relationship to genetic subtypes and age. J. Child Psychol. Psychiatry 2008, 9, 1001-1008. [CrossRef] [PubMed] 
6. Bennett, J.A.; Germani, T.; Haqq, A.M.; Zwaigenbaum, L. Autism spectrum disorder in Prader-Willi syndrome: A systematic review. Am. J. Med. Genet. A 2015, 167, 2936-2944. [CrossRef] [PubMed]

7. Buiting, K. Prader-Willi syndrome and Angelman syndrome. Am. J. Med. Genet. C Semin. Med. Genet. 2010, 154, 365-376. [CrossRef] [PubMed]

8. Sahoo, T.; del Gaudio, D.; German, J.R.; Shinawi, M.; Peters, S.U.; Person, R.E.; Garnica, A.; Cheung, S.W.; Beaudet, A.L. Prader-Willi phenotype caused by paternal deficiency for the HBII-85 C/D box small nucleolar RNA cluster. Nat. Genet. 2008, 40, 719-721. [CrossRef] [PubMed]

9. De Smith, A.J.; Purmann, C.; Walters, R.G.; Ellis, R.J.; Holder, S.E.; van Haelst, M.M.; Brady, A.F.; Fairbrother, U.L.; Dattani, M.; Keogh, J.M.; et al. A deletion of the HBII-85 class of small nucleolar RNAs (snoRNAs) is associated with hyperphagia, obesity and hypogonadism. Hum. Mol. Genet. 2009, 18, 3257-3265. [CrossRef] [PubMed]

10. Duker, A.L.; Ballif, B.C.; Bawle, E.V.; Person, R.E.; Mahadevan, S.; Alliman, S.; Thompson, R.; Traylor, R.; Bejjani, B.A.; Shaffer, L.G.; et al. Paternally inherited microdeletion at 15q11.2 confirms a significant role for the SNORD116 C/D box snoRNA cluster in Prader-Willi syndrome. Eur. J. Hum. Genet. 2010, 18, 1196-1201. [CrossRef] [PubMed]

11. Schaaf, C.P.; Gonzalez-Garay, M.L.; Xia, F.; Potocki, L.; Gripp, K.W.; Zhang, B.; Peters, B.A.; McElwain, M.A.; Drmanac, R.; Beaudet, A.L.; et al. Truncating mutations of MAGEL2 cause Prader-Willi phenotypes and autism. Nat. Genet. 2013, 45, 1405-1408. [CrossRef] [PubMed]

12. Kanber, D.; Giltay, J.; Wieczorek, D.; Zogel, C.; Hochstenbach, R.; Caliebe, A.; Kuechler, A.; Horsthemke, B.; Buiting, K. A paternal deletion of MKRN3, MAGEL2 and NDN does not result in Prader-Willi syndrome. Eur. J. Hum. Genet. 2009, 17, 582-590. [CrossRef] [PubMed]

13. Buiting, K.; di Donato, N.; Beygo, J.; Bens, S.; von der Hagen, M.; Hackmann, K.; Horsthemke, B. Clinical phenotypes of MAGEL2 mutations and deletions. Orphanet J. Rare Dis. 2014, 9. [CrossRef] [PubMed]

14. Matarazzo, V.; Muscatelli, F. Natural breaking of the maternal silence at the mouse and human imprinted Prader-Willi locus: A whisper with functional consequences. Rare Dis. 2013, 1, 1-7. [CrossRef] [PubMed]

15. Soden, S.E.; Saunders, C.J.; Willig, L.K.; Farrow, E.G.; Smith, L.D.; Petrikin, J.E.; Lepichon, J.; Miller, N.A.; Thiffault, I.; Dinwiddie, D.L.; et al. Effectiveness of exome and genome sequencing guided by acuity of illness for diagnosis of neurodevelopmental disorders. Sci. Transl. Med. 2014, 6, 1-14. [CrossRef] [PubMed]

16. Mejlachowicz, D.; Nolent, F.; Maluenda, J.; Ranjatoelina-Randrianaivo, H.; Giuliano, F.; Gut, I.; Sternberg, D.; Laquerrière, A.; Melki, J. Truncating mutations of MAGEL2, a gene within the Prader-Willi locus, are responsible for severe arthrogryposis. Am. J. Hum. Genet. 2015, 97, 616-620. [CrossRef] [PubMed]

17. Schaller, F.; Watrin, F.; Sturny, R.; Massacrier, A.; Szepetowski, P.; Muscatelli, F. A single postnatal injection of oxytocin rescues the lethal feeding behaviour in mouse newborns deficient for the imprinted MAGEL2 gene. Hum. Mol. Genet. 2010, 19, 4895-4905. [CrossRef] [PubMed]

18. Meziane, H.; Schaller, F.; Bauer, S.; Villard, C.; Matarazzo, V.; Riet, F.; Guillon, G.; Lafitte, D.; Desarmenien, M.G.; Tauber, M.; et al. An early postnatal oxytocin treatment prevents social and learning deficits in adult mice deficient for MAGEL2, a gene involved in Prader-Willi syndrome and autism. Biol. Psychiatry 2014, 78, 85-94. [CrossRef] [PubMed]

19. Bischof, J.M.; Stewart, C.L.; Wevrick, R. Inactivation of the mouse MAGEL2 gene results in growth abnormalities similar to Prader-Willi syndrome. Hum. Mol. Genet. 2007, 16, 2713-2719. [CrossRef] [PubMed]

20. Mercer, R.E.; Kwolek, E.M.; Bischof, J.M.; van Eede, M.; Henkelman, R.M.; Wevrick, R. Regionally reduced brain volume, altered serotonin neurochemistry, and abnormal behavior in mice null for the circadian rhythm output gene MAGEL2. Am. J. Med. Genet. B Neuropsychiatr. Genet. 2009, 150, 1085-1099. [CrossRef] [PubMed]

21. Mercer, R.E.; Wevrick, R. Loss of MAGEL2, a candidate gene for features of Prader-Willi syndrome, impairs reproductive function in mice. PLoS ONE 2009, 4, e4291. [CrossRef] [PubMed]

22. Tennese, A.A.; Wevrick, R. Impaired hypothalamic regulation of endocrine function and delayed counterregulatory response to hypoglycemia in MAGEL2-null mice. Endocrinology 2011, 152, 967-978. [CrossRef] [PubMed]

23. Hao, Y.-H.; Fountain, M.D.; Tacer, K.F.; Xia, F.; Bi, W.; Kang, S.-H.L.; Patel, A.; Rosenfeld, J.A.; Le Caignec, C.; Isidor, B.; et al. USP7 acts as a molecular rheostat to promote WASH-dependent endosomal protein recycling and is mutated in a human neurodevelopmental disorder. Mol. Cell 2015, 59, 956-969. [CrossRef] [PubMed]

(C) 2016 by the authors; licensee MDPI, Basel, Switzerland. This article is an open access article distributed under the terms and conditions of the Creative Commons by Attribution (CC-BY) license (http:/ / creativecommons.org/licenses/by/4.0/). 